\title{
TYLOTHRIPS BRUESI, A NEW THYSANOPTERON FROM FLORIDA
}

\author{
By J. Douglas Hood \\ Cornell University
}

The following species was taken within a few miles of Professor Charles T. Brues' home on the St. Johns River, in Florida, shortly after we had collected together and renewed an acquaintance which apparently began very nearly fifty years ago, long before he became Professor of Entomology at Harvard University and Editor of Psyche.

Tylothrips bruesi, sp. nov.

Text-figures 1 to 3 .

Like the Peruvian concolor Hood, the type of the genus and only known congener, in coloration and most structural features, but (1) head about 1.4 (instead of scarcely 1.2) times as long as width across eyes, (2) last two antennal segments much narrowed basally, thus not forming with segment VI a terminal club, (3) segment III of antennae longer (instead of much shorter) than IV, and with several of its more apical setae as long as the neighboring sensecones, (4) fore tibiae, only (instead of all three pairs), tuberculate along inner surface, (5) tube fully 2.3 (instead of less than twice) as long as its greatest subbasal width, and (6) major setae dull, or blunt, or very slightly dilated at tip (rather than broadly expanded).

o (macropterous). - Color of entire body, legs, and antennae blackish brown, with pedicel of antennal segment III and tip of tube somewhat paler and yellowish, IV-VI narrowly whitish just beyond the dark extreme base; internal pigmentation bright crimson-red, abundant in thorax and abdomen (exclusive of tube), sparse in head and first antennal segment; fore wings brown, darkest in anal area and with a dark median streak, which is narrowly edged with paler, extending to tip, the posterior margin pale between anal area and first fringing hair; 
major setae pale and yellowish, excepting the wing-retaining setae and the terminal ones, which are brown.

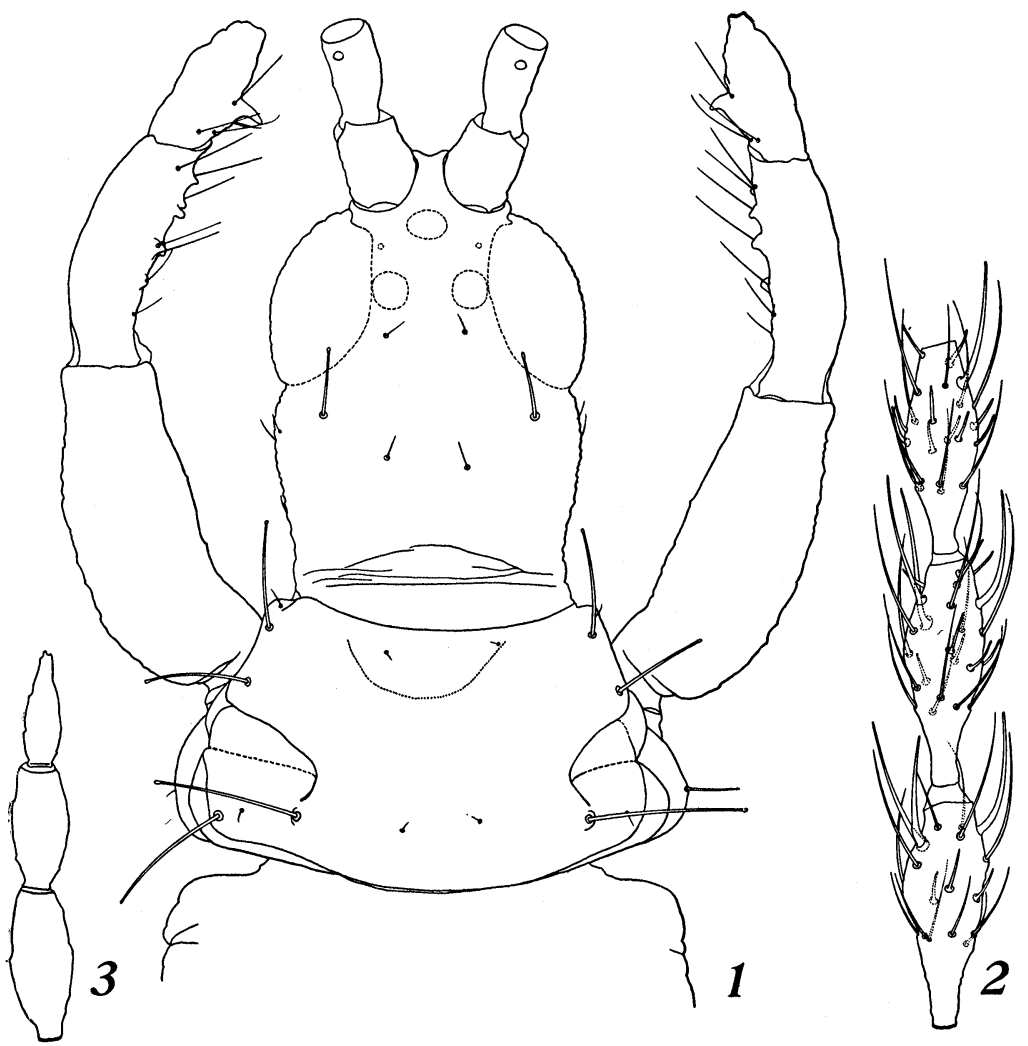

Text-figures 1 to 3 .

Tylothrips bruesi, sp. nov., $ᄋ$, holotype. Fig. 1.- Head and prothorax, $\mathrm{x}$ 176. (All setae omitted from femora, antennal segments, and outer surfaces of tibiae and tarsi; sculpture largely omitted; slight inaccuracies are to be expected in such details as the outlines of ocelli and of inner margins of eyes, because of the opacity of the specimen. It will be noted that the type lacks the right epimeral and left coxal setae.) Fig. 2. - Segments III-v, left antenna, x 236 (all setae shown). Fig. 3. - Segments vI-viII, right antenna, x 236 (all setae omitted).

The cost of the line engraving was borne by Cornell University through its Committee on Faculty Research Grants. 
Head (Fig. 1) slightly produced between eyes and antennae, fully 1.4 times as long as greatest width across eyes, this width somewhat greater than that across cheeks slightly behind eyes; sides of head incised at posterior margin of eyes; cheeks rounded and converging to near base, where the least width is about 0.86 the width across eyes, serrate as seen from above because of rather heavy anastomosing lines; frontal costa with a shallow rounded groove; postocular setae approximately 45 microns long, 121 microns apart, slightly dilated at tip. Eyes prominent, large, protruding, slightly less than one-half the length of head, their dorsal length 106 microns. Median ocellus with front margin on line with that of eyes. Antennae long and slender, about 2.24 times the length of head, their last three segments (Fig. 3) not at all united, the pedicels of VII and VIII not broad; III somewhat longer than either IV or V (Fig. 2), with several very fine, indistinct, transverse lines of sculpture on pedicel; major sense-cones long and slender, disposed as follows on inner (and outer) surfaces of segments: III 1(2), IV 1(2), V 1(1), VI 1(1), VII 1 dorsal; III and IV with several additional minor sense-cones; major antennal setae long and pointed, those associated with the major sense-cones about equal to them in length. Mouthcone short, nearly semicircularly rounded at tip, extending about 70 microns beyond posterior dorsal margin of head.

Prothorax (Fig. 1), along median line of pronotum, about 0.63 the length of head and one-half the width across fore coxae, its surface nearly smooth but with a few faint lines of sculpture near posterior margin; posterior half of epimera fused with pronotum; antero-marginal setae very minute, the other usual setae long, moderately heavy, and very slightly widened at tip, the antero-angulars and midlaterals about 73 microns, epimerals and postero-marginals 87-91, coxals about 33. Pterothorax rather long, wider than prothorax across coxae; metanotal plate in basal half, shield-shaped and roundly elevated, its posterior part without distinct foveae at sides, the single pair of major setae pointed, 43 microns long and 78 microns apart. Legs moderately long and slender, the fore tibiae (Fig. 1) with several strong tubercles from each of which arises a 
long pointed seta, mid and hind tibiae without much tubercles; fore tarsi with a strong and somewhat recurved tooth on inner surface. Fore wings straight, narrowed slightly and evenly to tip, not closely fringed, without accessory setae on posterior margin, the subbasal setae blunt (asymmetrically disposed in type).

Abdomen without distinct sculpture; major setae mostly slightly broadened at tip (excepting the wing-retaining ones, seta III on IX, and the terminal ones, all of which are pointed), I on IX 103 microns, II 132, III 109, terminal 120; tube ( $\mathrm{x}$, only) about 0.7 the length of head and fully 2.3 times as long as greatest subbasal width, its sides slightly concave beyond base, then straightly converging to tip.

Measurements of $\&$ (holotype), in mm.: Length about 1.9 (fully distended, 2.43) ; head, total length 0.258 , width across eyes 0.182 , least width behind eyes 0.164 , greatest width across cheeks 0.179 , least width near base 0.158 , width in front of eyes 0.093 ; pronotum, median length 0.154 ; prothorax, width across fore coxae 0.304 ; mesothorax, width across anterior angles 0.305 ; metathorax, greatest width 0.325 ; fore wings, length 0.962 , width at middle 0.061 ; abdomen, greatest width (at segment IV) 0.354 ; tube (segment $\mathrm{x}$, only), length 0.178 , greatest subbasal width 0.077 , width at apex 0.041 .

$\begin{array}{lllllllll}\text { Antennal segments: I } & \text { II } & \text { III } & \text { IV } & \text { v } & \text { vI } & \text { vII } & \text { vIII }\end{array}$

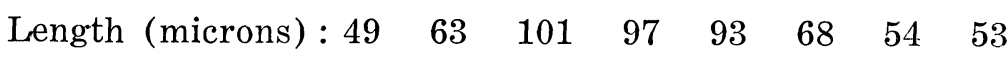

Width (microns) : $\begin{array}{llllllll}44 & 30 & 36 & 36 & 32 & 27 & 25 & 17\end{array}$

Total length of antennae, $0.578 \mathrm{~mm}$.

FlORIDA: Welaka (Conservation Reserve, University of Florida), August 12, 1954, J. D. H., 1 \& (holotype), from dead fallen branches of Turkey Oak (Quercus laevis), in open sandy woods.

This is the second species of the genus Tylothrips, which the writer erected in 1937 for a Peruvian species that came from dead branches and leaves. The two are almost identical in color and general appearance and could easily be confused with each other. 


\title{
AN EOCENE BITTACUS (MECOPTERA) ${ }^{1}$
}

\author{
By F. M. Carpenter \\ Harvard University
}

In $1928^{2}$ I described, as Palaeobittacus eocenicus, a species of the family Bittacidae from Eocene strata in Colorado. This has been the only representative of the Mecoptera in Eocene deposits and the earliest unquestionable record of a living family of the order. A second Eocene bittacid has now turned up, this time among an extensive collection of insects which Dr. Carl Parsons and I made nearly twenty years ago in Utah. It appears to be a true Bittacus with characteristic wing venation and body features.

\section{Genus Bittacus Latr.}

Bittacus egestionis, n. sp.

(Figures 1 and 2)

Fore wing: $8 \mathrm{~mm}$. long; maximum width, $2 \mathrm{~mm}$.; antennae $2 \mathrm{~mm}$. long; body $7 \mathrm{~mm}$. long; wings without mark-

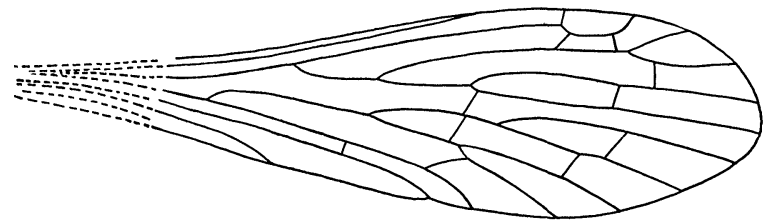

Figure 1. Drawing of fore wing of Bittacus egestionis, n. sp.

ings; venation and wing form as shown in figure 2 ; cubital cross-vein below the first fork of $\mathrm{M}$; two pterostigmal cross-veins apparently present; hing wings somewhat more slender than fore wings.

${ }^{1}$ Published with a grant from the Museum of Comparative Zoology at Harvard College.

${ }^{2} \mathrm{~A}$ Scorpion-fly from the Green River Eocene. Annals Carnegie Museum, 28: 240-249. 1928. 

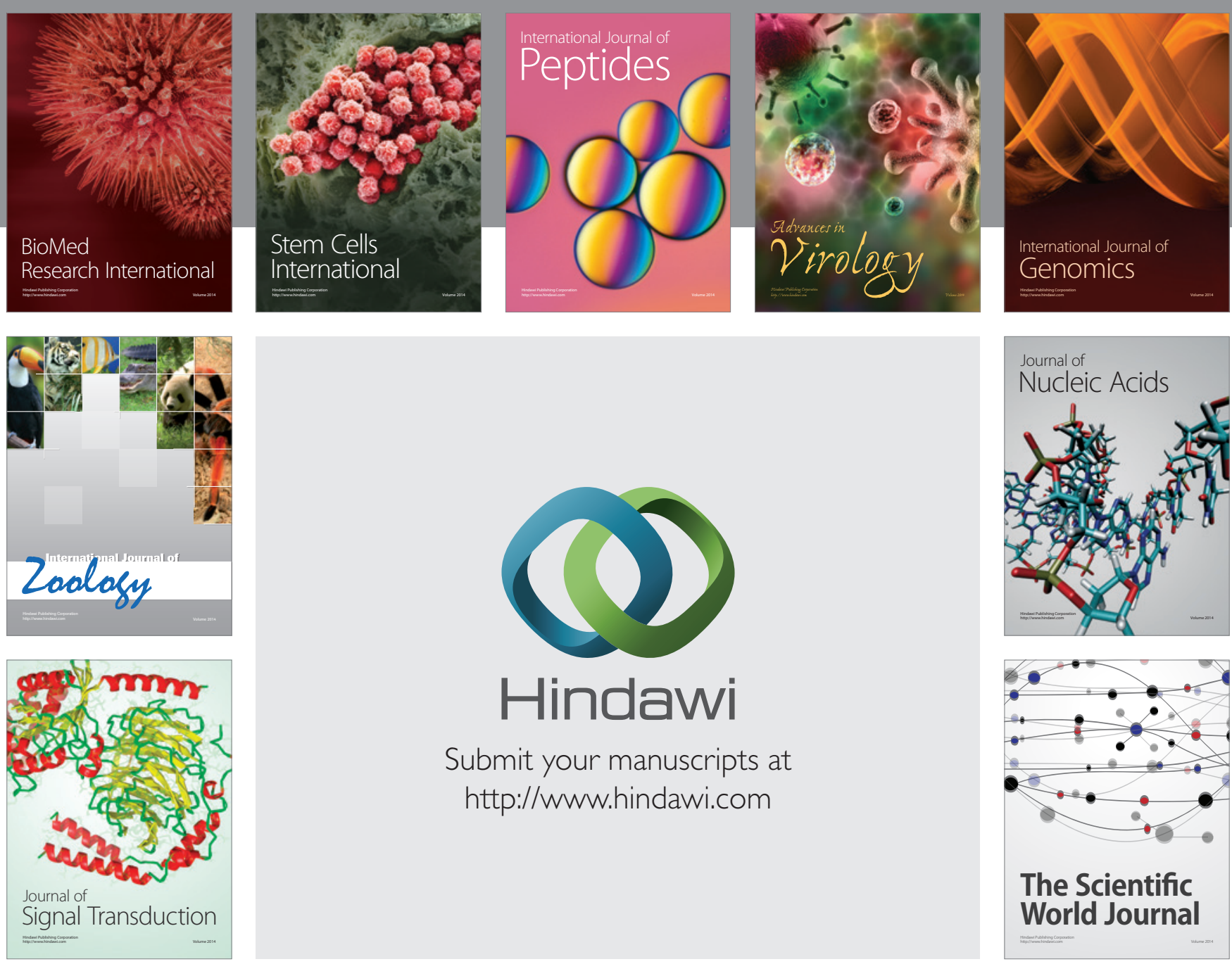

Submit your manuscripts at

http://www.hindawi.com
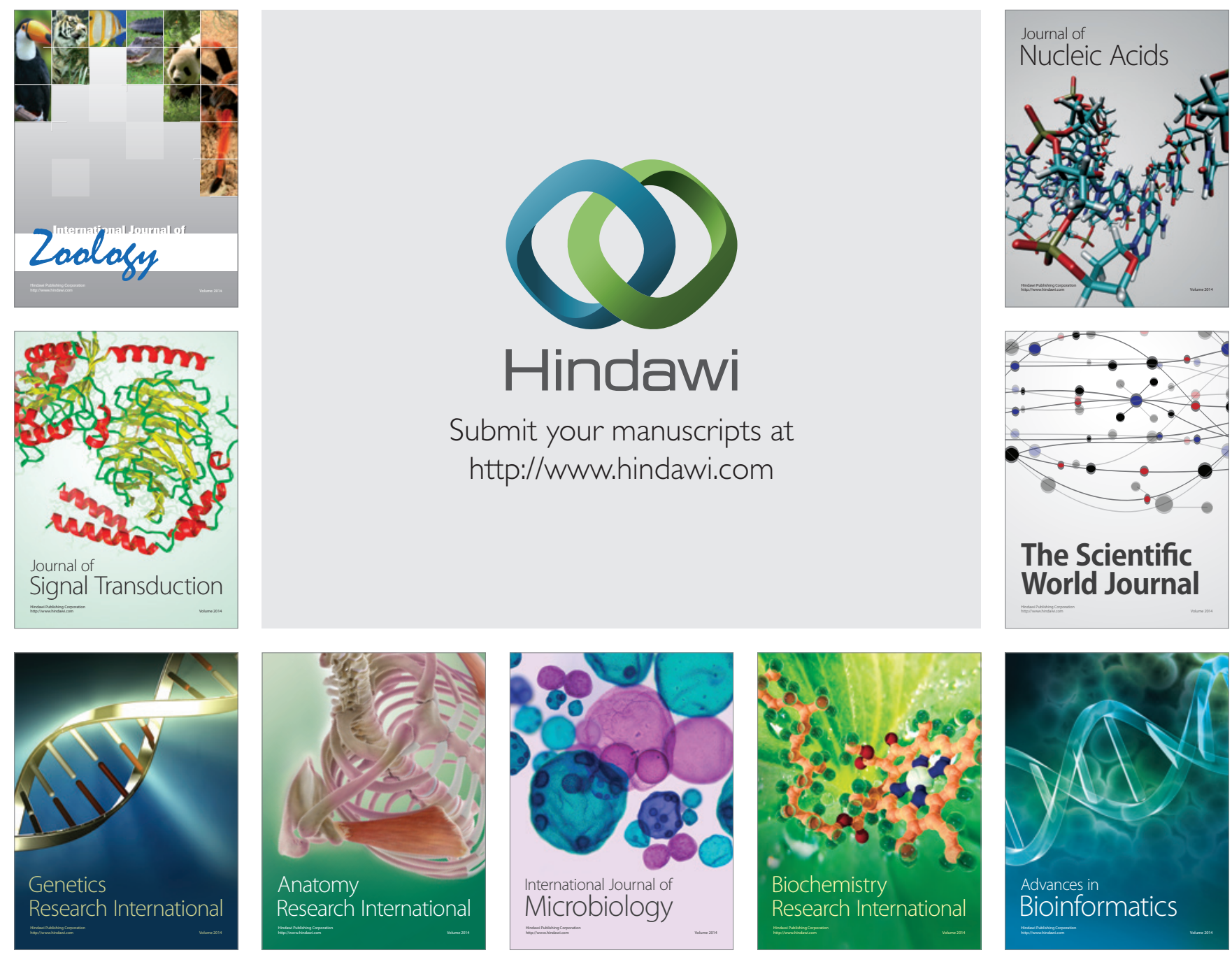

The Scientific World Journal
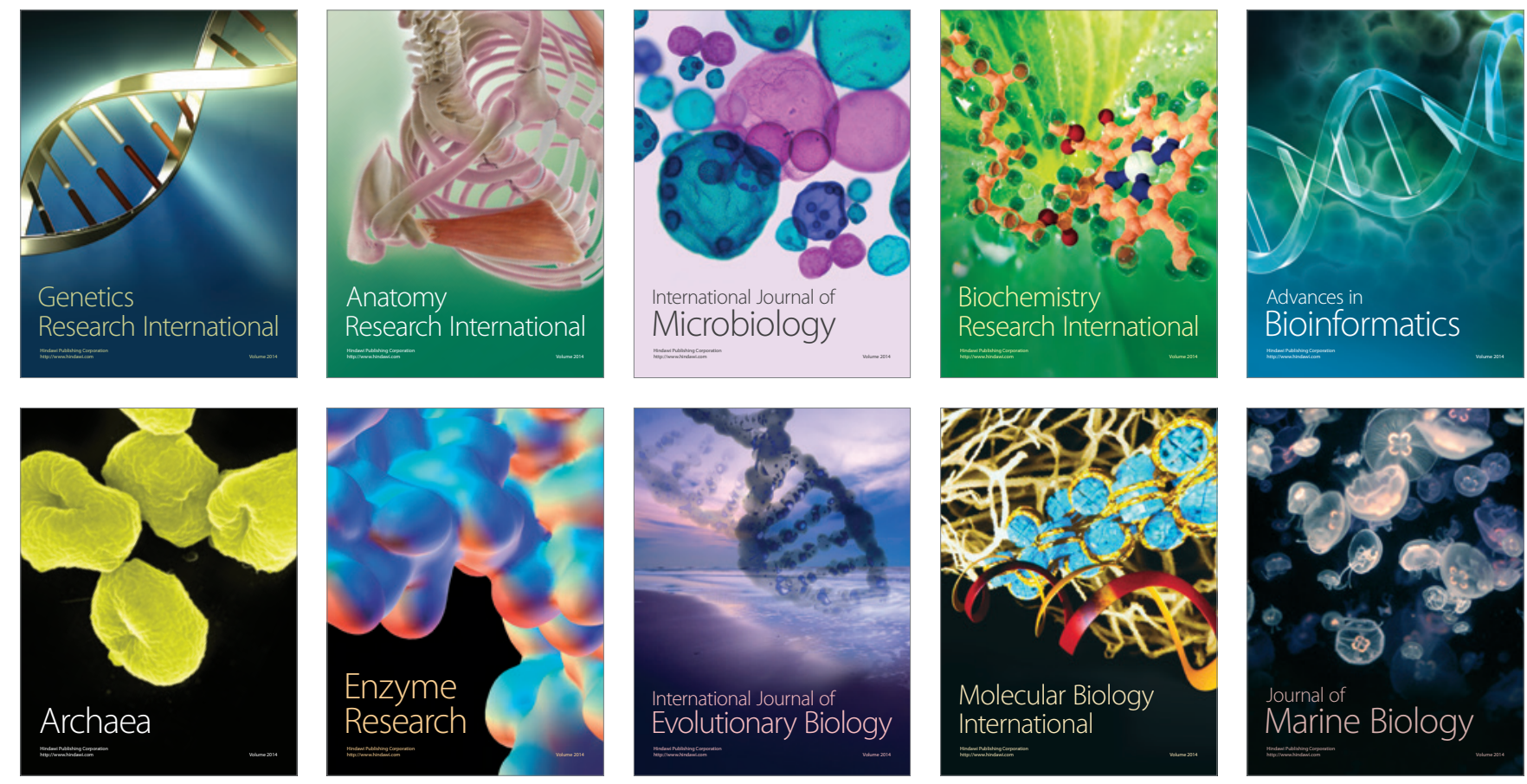